\title{
Rainfall- Runoff Modelling Using SCS-CN Method: A Case Study of Krishnagiri District, Tamilnadu
}

\author{
R. Vinithra ${ }^{1}$, L. Yeshodha \\ ${ }^{1}$ Pg student, M Tech (RS) Department of Civil Engineering, Adhiyamaan College of Engineering, Hosur. \\ ${ }^{2}$ Professor, Department of Civil Engineering, Adhiyamaan College of Engineering, Hosur
}

\begin{abstract}
Runoff is one of the most important hydrological variables used in most of the land and water resources applications. The determination of surface runoff at micro level is essential to address soil and water conservation practices in a watershed. Understanding the basic relationships between rainfall, runoff and soil loss are studied for effective management and utilization of water resources and soil conservation service. Curve Number (CN) method is mainly used for estimating infiltration characteristics of the watershed, based on the land use property and soil property. In the present study an attempt is made to estimate the surface runoff for Krishnagiri district, Tamil Nadu using SCS- CN method. Hydrological soil group (HSG), land use / land cover Map, Soil and multi spectral remote sensing data are used for the analysis. Runoff is computed for different areas barren land, agriculture, industrial, forest .Based on these derived information soil classification falls under group $C$. The estimated amount of average annual surface runoff is $76.53 \mathrm{~mm}$, which is corresponds to $54 \%$ of annual average rainfall of Krishnagiri district. These details is useful to identifying runoff potential in Krishnagiri district and developing appropriate soil and water conservation structures.
\end{abstract}

Keywords: Rainfall, Runoff, SCS Curve Number, Remote Sensing and GIS

\section{Introduction}

The problem most often encountered in hydrological studies is the need for estimating runoff from a watershed for which there is records of precipitation and no records of runoff. The SCS-CN is an empirical parameter used in hydrology for predicting direct runoff or infiltration from rainfall excess. The curve number method was developed by the USDA natural resources conservation service which was formerly called the soil conservation service or SCS. The curve number is depending on the soil type, effects of land use and cover, hydrologic condition. A rainfall runoff model can be really helpful to the present work in the case of calculating discharge from a basin. The transformation of rainfall into runoff over a catchment is known to be very complex hydrological phenomenon, as this process is highly nonlinear, time- varying and spatially distributed. Over the years researchers have developed many models to simulate this process.

The Soil Conservation Services (SCS) runoff model is useful for evolving the runoff potential for every feature utilizing different antecedent moisture condition (AMC) to obtain runoff potential layer and for computing the peak runoff rate. The peak runoff rate can be utilized to calibrate the conventional rational formula. The sites for water conservation measures not only depend on annual rainfall but also on other terrain factors like, slope, aspect, ground undulations, soil permeability and land use variation in space and time. In this study SCS CN modified for Indian condition has been used for generation of runoff of the study area.

Remote sensing Techniques are more reliable, up-to-date, and faster than conventional techniques. It plays a vital role in acquisition of data in the different aspects of land use and soil cover, which are essential parameters in the field of watershed runoff estimation. GIS is capable of handling spatial and aspatial data when compared to conventional information system. It also identifies the spatial relationships between map features. The use of GIS technology as a spatial data management and an analysis tool provides an effective mechanism for hydrologic/ hydraulic studies.

\section{Study Area}

Krishnagiri district is bounded by Vellore and Thiruvannamalai districts in the East, Karnataka state in the west, State of Andhra Pradesh in the North Dharmapuri District in the south. Its area is $5143 \mathrm{Sq}$. Kms. This district is elevated from $300 \mathrm{~m}$ to $1400 \mathrm{~m}$ above the mean sea level. It is located between $11^{\circ} 12^{\prime} \mathrm{N}$ to $12^{\circ} 49^{\prime} \mathrm{N}$ Latitude, $77^{\circ} 27^{\prime} \mathrm{E}$ to $78^{\circ} 38^{\prime} \mathrm{E}$ Longitude. Eastern part of the district experiences hot climate and Western part has a contrasting cold climate.

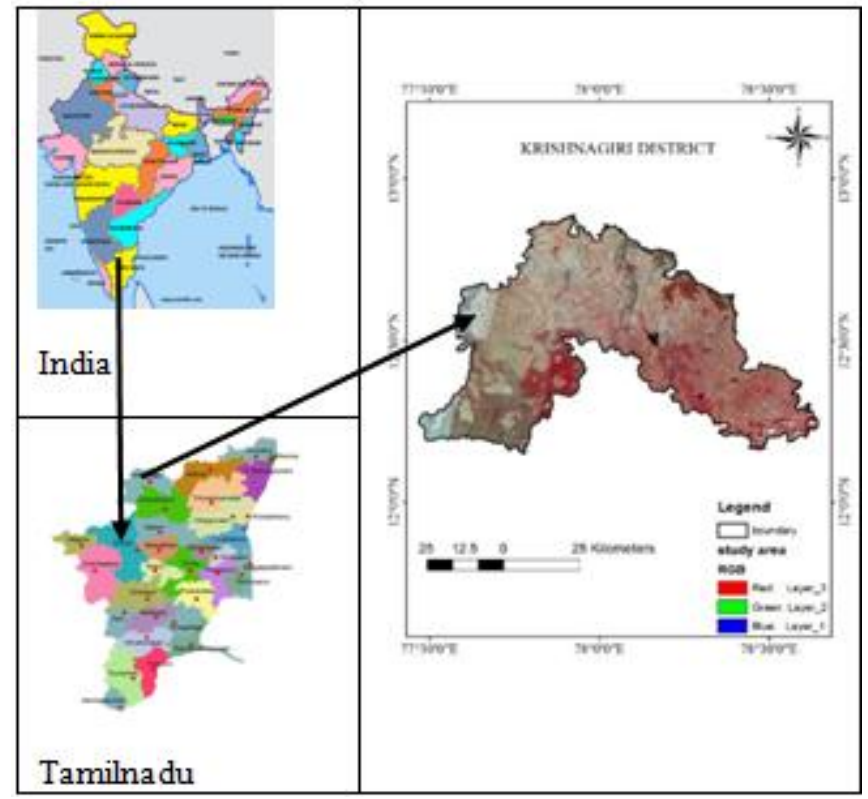

Figure 1: Study Area Map 


\section{International Journal of Science and Research (IJSR) \\ ISSN (Online): 2319-7064}

Index Copernicus Value (2013): 6.14 | Impact Factor (2014): 5.611

The average rainfall is $830 \mathrm{~mm}$ per annum. The main rivers that flow across the district are Kaveri and South Pennar Kaveri enters the district from South West in Denkanikottai taluk and exists in South West direction. It forms waterfalls at Hokenakkal and joins Mettur Dam. South Pennar originates in Nandidurg of Karnataka and flows through Hosur, Krishnagiri and Uthangari Taluks. Vanniyar and Markanda rivers join this South Pennar

\section{Material And Methodology}

The dataes collected for the studies are

The satellite data used for the study is IRS P6 (LISS IV) of $13^{\text {th }}$ February 2012 which is collected from the National Remote Sensing Centre (NRSC) Hyderabad.The toposheets used for the study 57H/10 ,57H/11,57H/12,57H/13,57H/14 , 57H/15 , 57L/1 ,57L/2, 57L/3, 57L/ 6, 57L/7, 57L/8, 57L/11 and $57 \mathrm{~L} / 12$ of $1: 50000$ scale. The toposheets are collected from the Tamilnadu State Capital Survey of India (SOI), Chennai. Rainfall data for the period of 14 years (2000-2013).The delineation of the watershed is done using the software arc map 10

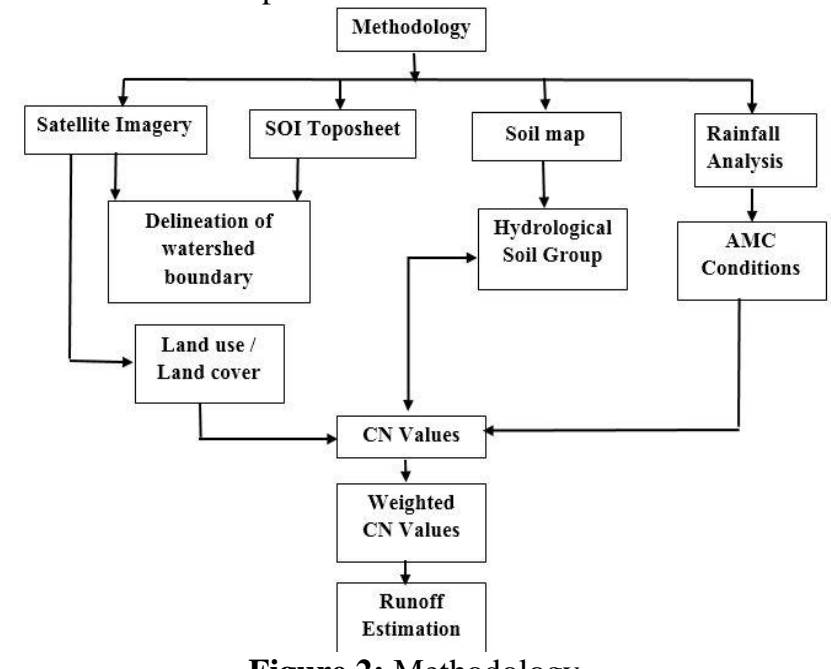

Figure 2: Methodology

\section{SCS-CN Method of Estimating Runoff}

SCS-CN method developed by Soil Conservation Services (SCS) of USA in 1969 is a simple, predictable and stable conceptual method for estimation of direct runoff depth based on storm rainfall depth. It is a versatile and widely used procedure for runoff estimation. The SCS approach involves the use of simple empirical formulas and readily available tables and curves, developed by the Soil Conservation Service (SCS, 1985). The curve numbers are varied for different soil, land use/land cover and hydrologic conditions. Although the method is designed for a single rainfall event, it can be scaled to find average runoff (Amstutz et al, 2008).The SCS runoff expressed in unit depth spread over the watershed is given by

$$
\mathbf{Q}={\frac{(\mathbf{P}-0.2 \mathrm{~S})^{2}}{\mathbf{P}+0.8 \mathrm{~S}}}^{\mathbf{2}}
$$

Where, Q direct flow volume expressed as a depth, $\mathrm{P}$ total rainfall, $\mathrm{S}$ potential maximum soil retention, $\mathrm{CN}$ curve number value used to estimate potential maximum soil retention (S)

$$
S=\frac{25,400}{C N}-24
$$

The CN values were tabulated according to the NRSC TR 55 for various land covers and soil textures. These values were developed fromannual flood rainfall-runoff data from the literature for a variety of watersheds generally less than one square $\mathrm{km}$ in area (USDA-SCS 1985). For runoff estimation in a basin, the results: curve number $(\mathrm{CN})$, potential maximum soil retention $(\mathrm{S})$, initial abstraction $\left(\mathrm{I}_{\mathrm{A}}\right)$ and antecedent moisture condition are required.

\section{Weighted Curve Number}

$$
=\frac{\sum(\mathbf{C N} 1 * \mathbf{A} 1+\mathbf{C N} 2 * \mathbf{A} 2+\cdots \mathbf{C N n} * \mathbf{A n})}{\sum \mathbf{A}}
$$

Where, CN1 curve number for particular land unit 1, a1 area for that particular land unit 1, $\sum \mathrm{A}$ sum of total area. After calculating the weighted curve number, the potential maximum soil retention (S) was calculated for each watershed by using the following formula

$$
S=\frac{25,400}{C N}-24
$$

The potential maximum soil retention estimation, the initial abstractions $\left(\mathrm{I}_{\mathrm{A}}\right)$ are calculated. Initial abstractions are water losses, e.g. plant interceptions, infiltration and surface storage which occur prior to runoff and are then subtracted from the total runoff (USDA-SCS 1985). The standard assumption is that

$$
I_{\mathrm{A}}=0.2 \mathrm{~S}
$$

If rainfall is greater than $.2 \mathrm{~S}$, then there is a possibility of runoff. Otherwise, if rainfall is less than $0.2 \mathrm{~S}$, runoff will be zero. Hence, the rainfall events, which are more than $0.2 \mathrm{~S}$, were considered for further runoff estimation.

\section{Antecedent Moisture Conditions (AMC)}

The antecedent moisture condition refers to the water content present in the soil at a given time. It is determined by total rainfall in 5-day period preceding a rainfall event (SCS, 1986). There are three antecedent soil-moisture conditions (I, II \& III) according to different soil conditions and rainfall limits for dormant and growing seasons (Table 1). The AMC-I, indicates the lowest runoff potential because the soils are dry enough, AMC-II indicates the average soil moisture condition and AMC-III indicates highest runoff potential of the soil, which practically happens when areas of watershed are saturated from antecedent rains. The value of CN for different land use conditions and hydrologic soil group are given in standard curve number tables (SCS, 1986). These values are applied only to AMC-II and in order to derive curve number values for AMC-I and III, the following correction factors need to be applied (Rao et al., 2010).If the antecedent moisture condition is I (dry), the curve number is adjusted down by using the following formula

$$
\mathrm{CN}=0: 39 * \mathrm{CN} * \exp (0.009 * \mathrm{CN})
$$

And if the antecedent moisture condition is III (wet), the curve number is adjusted up by using the following equation.

$$
\mathrm{CN}=1.95 * \mathrm{CN} * \exp (-0.00663 * \mathrm{CN})
$$

Suppose the antecedent moisture condition is II (damn), the same weighted curve number is used for runoff estimation. 


\section{International Journal of Science and Research (IJSR) \\ ISSN (Online): 2319-7064}

Index Copernicus Value (2013): 6.14 | Impact Factor (2014): 5.611

Table 1: Classification of antecedent moisture conditions

(SCS, 1986)

\begin{tabular}{|c|c|c|}
\hline AMC CLASS & Dormant Season & Growing Season \\
\hline I & $<12.5$ & $<35$ \\
\hline II & 12.5 to 27.5 & 35 to 52.5 \\
\hline III & $>27.5$ & $>52.5$ \\
\hline
\end{tabular}

\section{Results and Discussion}

In this section results for SCS model estimated runoff for south pennar river basin of Krishnagiri district are presented. In order to estimate the surface runoff, $\mathrm{CN}$ values based on HSGs and LU/LC map are required. Hence, HSG and land use/land cover map of the watershed was prepared with the help of remote sensing and GIS.

\section{Hydrological Soil Group (HSG)}

Soils are classified by the natural resource conservation service in four hydrologic soil group based on the soils group are A, B, C and D. details of this classification can be found in ,urban hydrology for small watersheds ${ }^{\text {ee }}$ published by the engineering division of the natural resource conservation service, USDA, TR-55The hydrologic soil groups of the study area have been identified corresponding to the standard HSGs and their textural classes as presented in the table 2 and figure 4.

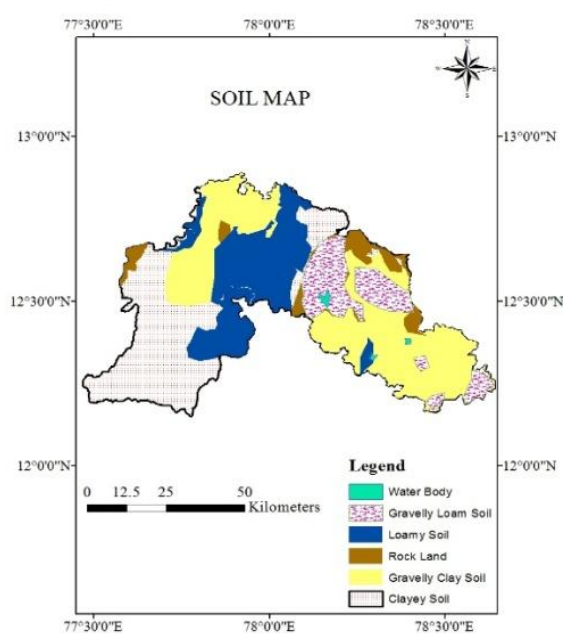

Source: Tamilnadu soils

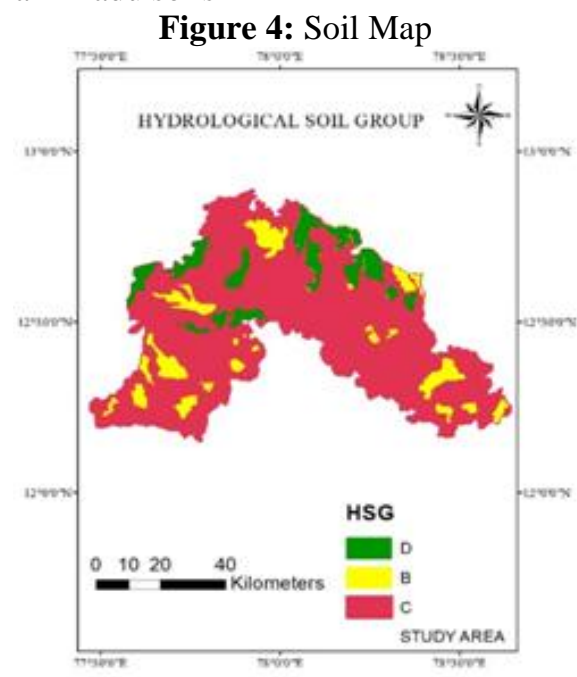

Table 2: USDA-SCS Hydroogical Soil Classcification

\begin{tabular}{|c|c|c|}
\hline \begin{tabular}{|c|} 
Hydrological \\
Soil Group
\end{tabular} & Description & $\begin{array}{c}\text { Soil } \\
\text { Texture }\end{array}$ \\
\hline Group A & $\begin{array}{c}\text { These soils have low runoff potential and } \\
\text { high infiltration rates even when } \\
\text { thoroughly wetted they consist of chiefly } \\
\text { of deep, well to excessively drained sands } \\
\text { or gravels and have a high rate of water } \\
\text { transmission. ( }>0.30 \text { in/hr.). } \\
\end{array}$ & $\begin{array}{l}\text { Sand, } \\
\text { loamy } \\
\text { sand or } \\
\text { sandy } \\
\text { loam }\end{array}$ \\
\hline Group B & $\begin{array}{c}\text { These soils have moderate infiltration } \\
\text { rates when thoroughly wetted and consist } \\
\text { chiefly of moderately deep to deep, } \\
\text { moderately well to well drained soils with } \\
\text { moderately fine to moderately coarse } \\
\text { textures. These soils have a moderate rate } \\
\text { of water transmission }(0.15-0.30 \mathrm{in} / \mathrm{hr} .)\end{array}$ & $\begin{array}{l}\text { Silt loan } \\
\text { or loam, } \\
\text { gravelly } \\
\text { loam } \\
\text { soils }\end{array}$ \\
\hline $\mathrm{GI}$ & $\begin{array}{c}\text { These soils have low infiltration rates } \\
\text { when thoroughly wetted and consist } \\
\text { chiefly of soils with a layer that impedes } \\
\text { downward movement of water and soils } \\
\text { with moderately fine to fine texture. } \\
\text { These soils have a low rate of water } \\
\text { transmission }(0.05-0.15 \mathrm{in} / \mathrm{hr} .) . \\
\end{array}$ & $\begin{array}{l}\text { Gravelly } \\
\text { loam } \\
\text { soils, } \\
\text { clayey } \\
\text { soils. }\end{array}$ \\
\hline $\mathrm{pD}$ & $\begin{array}{l}\text { These soils have high runoff potential. } \\
\text { They have very low infiltration rates } \\
\text { when thoroughly wetted and consist } \\
\text { chiefly of clay soils with a high swelling } \\
\text { potential, soils with a permanent high } \\
\text { water table, soils with a clay pan or clay } \\
\text { layer at or near the surface, and shallow } \\
\text { soils over nearly impervious material. } \\
\text { These soils have a very low rate of water } \\
\text { transmission }(0-0.05 \mathrm{in} / \mathrm{hr} \text {.). }\end{array}$ & $\begin{array}{c}\text { Rocky } \\
\text { outcrops } \\
\text { clayey } \\
\text { soils }\end{array}$ \\
\hline
\end{tabular}

\section{Land use/landcover}

The land use /land cover analysis is the important phenomena which deals with the great emphasis of past and present. The land cover features are identified from the satelite data IRS P6(LISS IV). The land cover features identified inthe study area are crop land, plantation, fallow land, river,waterbodies, barren rocky, cultivable land,open scrub, scrub forest, rural built up,urban builtup, scrub forest and current shifting cultivation. The land use land cover details shown in Table 3,4 and Fig 5

Table 3: Area of different land use and land cover

\begin{tabular}{|c|c|}
\hline LU/LC TYPE & AREA(HECTARES) \\
\hline FOREST (Dense) & 110,400 \\
\hline FOREST(Open) & 37800 \\
\hline AGRICULTURE & 100,300 \\
\hline WATER & 7200 \\
\hline BARREN LAND & 39900 \\
\hline SCRUB & 62400 \\
\hline SETTLEMENT & 69000 \\
\hline FALLOW LAND & 27800 \\
\hline
\end{tabular}

Figure 4: HSG Map 


\section{International Journal of Science and Research (IJSR) \\ ISSN (Online): 2319-7064}

Index Copernicus Value (2013): 6.14 | Impact Factor (2014): 5.611

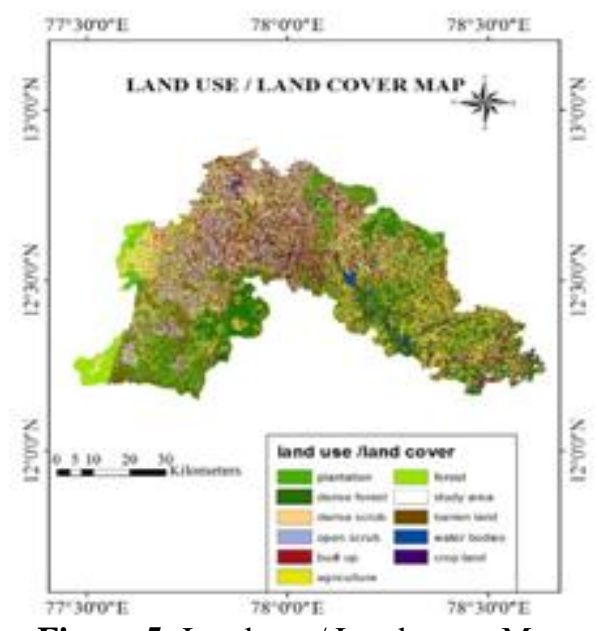

Figure 5: Land use / Land cover Map

Table 4: CN values for LU/LC classes adopted in this study (SCS, 1986; Rao et al., 2010)

\begin{tabular}{|c|c|c|c|c|}
\hline \multirow{2}{*}{ LU/LC CLASSES } & \multicolumn{4}{|c|}{ Hydrological Soil Group } \\
\cline { 2 - 5 } & $\mathrm{A}$ & $\mathrm{B}$ & $\mathrm{C}$ & $\mathrm{D}$ \\
\hline FOREST (Dense) & 48 & 67 & 77 & 83 \\
\hline FOREST (Open) & 68 & 79 & 86 & 89 \\
\hline SETTLEMENT & 48 & 66 & 78 & 83 \\
\hline AGRICULTURE & 67 & 78 & 85 & 89 \\
\hline PLANTATION & 65 & 73 & 79 & 81 \\
\hline FALLOW & 76 & 85 & 90 & 93 \\
\hline SCRUB & 48 & 67 & 77 & 83 \\
\hline BARREN LAND & 64 & 75 & 83 & 85 \\
\hline WATER & 90 & 94 & 98 & 100 \\
\hline
\end{tabular}

\section{Delineation of Watershed}

Watershed- land area that drains water to the outlet during a rainstorm boundary of a watershed consist of the line drawn across the contour joining the highest elevation surrounding the basin. In the study area the main watersheds are Upper Ponniyar, Kuppakode, Maathur, Pullampatti,Arkavati, and Chinnar Dodda. Details of Basin, sub-catchment and watershed areas are as follows table 4

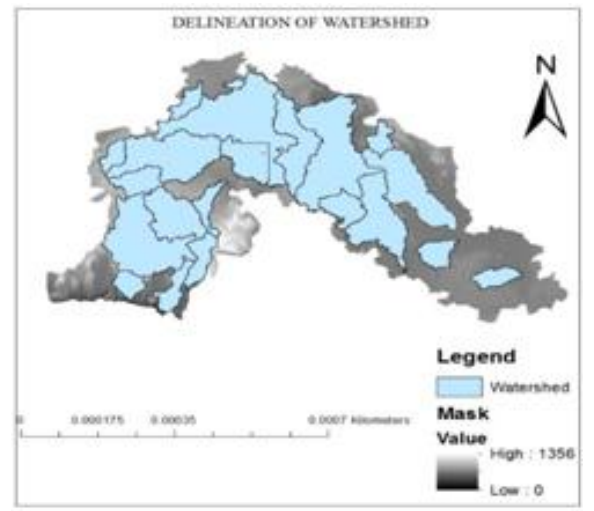

Figure 6: Delineation of Watershed

Table 4: Details of basin and sub basin

\begin{tabular}{|c|c|c|c|c|}
\hline $\begin{array}{c}\text { S. } \\
\text { NO }\end{array}$ & Basin & Catchment & $\begin{array}{c}\text { Sub- } \\
\text { Catchment }\end{array}$ & Watershed \\
\hline 1 & $\begin{array}{c}\text { East Coast } \\
\text { Minor } \\
\text { Rivers }\end{array}$ & $\begin{array}{c}\text { Between } \\
\text { Cauvery and } \\
\text { Palar }\end{array}$ & $\begin{array}{c}\text { Upper } \\
\text { ponnaiyar } \\
\text { beyond } \\
\text { Sattanur dam }\end{array}$ & $\begin{array}{c}\text { Upper ponnaiyar } \\
\text { Kuppakode } \\
\text { Mathur } \\
\text { Pullampatti }\end{array}$ \\
\hline 2. & Cauvery & $\begin{array}{c}\text { Stanley } \\
\text { reservoir to } \\
\text { Krishnarajasagar }\end{array}$ & L.B Cauvery & $\begin{array}{c}\text { Arkavati } \\
\text { Chinnar dodda }\end{array}$ \\
\hline
\end{tabular}

\section{Weighted curve number}

In order to standardize the curve numbers, weighted hydrologic curve number was determined for Krishnagiri district. In the present study, 36 number of LU/LC-HSG units were identified.The weighted curve number obtained from the calculations for AMC-II is 85, corresponding to this, curve numbers for AMC I and AMC III were determined using the equations 5 and 6 . The curve number for the AMC-I is 70 and AMC-III is 93

\section{Runoff Estimation}

The daily rainfall data for 14 years from 2000 to 2013 were collected from the Groundwater Department. The initial abstractions $\left(\mathrm{I}_{\mathrm{A}}\right)$ were calculated for each watershed (explained under the Soil Conservation Services (SCS) curve method). If a storm event is less than the initial abstraction value, there is a runoff available for that rainfall event. The runoff details are shown in table 6

Table 6: Runoff estimation for different rainfall events using hydrological weighted curve numbers

\begin{tabular}{|c|c|c|c|}
\hline Year & Annual Rainfall & AMC Class & Annual Runoff \% \\
\hline 2000 & 1261.3 & III & 67 \\
\hline 2001 & 1825 & III & 72 \\
\hline 2002 & 781.1 & I & 28 \\
\hline 2003 & 1027.8 & III & 63 \\
\hline 2004 & 884.8 & II & 55 \\
\hline 2005 & 1373.1 & III & 69 \\
\hline 2006 & 483.25 & I & 16 \\
\hline 2007 & 1062.1 & III & 59 \\
\hline 2008 & 1412.6 & III & 70 \\
\hline 2009 & 1204 & III & 64 \\
\hline 2010 & 1301.73 & III & 66 \\
\hline 2011 & 911.3 & II & 59 \\
\hline 2012 & 695.1 & I & 21 \\
\hline 2013 & 766 & I & 48 \\
\hline
\end{tabular}

These details is useful to identifying runoff potential in Krishnagiri district and developing appropriate soil and water conservation structures. After calculating the curve number $(\mathrm{CN})$, potential maximum soil retention $(\mathrm{S})$, initial abstraction $\left(\mathrm{I}_{\mathrm{A}}\right)$ and antecedent moisture condition, runoff was calculated for south pennar and Cauvery river basins. Excess runoff and low infiltration occurred in Denkanikottai taluk and some part of Krishnagiri taluk. And rest of the parts having medium to high runoff and medium infiltration.

\section{Conclusion}

In this analysis it is concluded that the runoff mainly depends upon rainfall and soil texture. SCS model has been used to estimate runoff. This model gives quick estimate of generated runoff in a particular location with reasonably good accuracy but doesn't take into account flow processes due to topographical variations. The curve number model predictions are found to be lower than actual observe direct runoff for the watershed. The initial abstraction represents all losses before runoff begins, and includes Water retained in surface depression, water taken up by vegetation, evaporation, and infiltration. 


\section{International Journal of Science and Research (IJSR) \\ ISSN (Online): 2319-7064}

Index Copernicus Value (2013): 6.14 | Impact Factor (2014): 5.611

\section{Acknowledgement}

The authors wish to express sincere thanks to the Head of the Department, Adhiyamaan College of engineering for providing all necessary institutional support

\section{References}

[1] Dhawale, A. W. (2013). Runoff Estimation for Darewadi Watershed using RS and GIS. International Journal of Recent Technology and Engineering, 1(6), 46-50.

[2] Ebrahimian, M., See, L., \& Abdul Malek, I. (2009). Application of natural resources conservation servicecurve number method for runoff estimation with GIS in the Kardeh watershed, Iran. European Journal of scientific research, 34(4), 575-590.

[3] Giridhar, M. V. S., \& Viswanadah, G. K. (2009). Runoff estimation in an ungagged watershed using RS and GIS. J. Indian Water Works Assoc., 3, 32-49.

[4] Kumar, P. S., Babu, M. R. K., \& Praveen, T. V. (2010). Analysis of the runoff for watershed using SCS-CN method and geographic information systems. International Journal of Engineering Science and Technology, 2(8), 3947-3654.

[5] S.Anbazhagan, S.M. Ramasamy, S. Das Gupta, "Remote Sensing and GIS For Artificial Recharge Study, Runoff Estimation and Planning In Ayyar Basin," Tamil Nadu, India, Research gate, Vol 48, pp.158-170, 2005

[6] Rao, K. N., Narendra, K., \& Latha, P. S. (2010). An integrated study of geospatial information technologies for surface runoff estimation in an agricultural watershed, India. Journal of the Indian Society of Remote Sensing, 38(2), 255-267

[7] Saravanan, S., \& Manjula, R. (2015). Geomorphology Based Semi-distributed Approach for Modeling Rainfall-runoff Modeling Using GIS. Aquatic Procedia, 4, 908-916.

[8] Soil Conservation Service (1986), Urban Hydrology for Small Watersheds. Technical Release 55, United States Department of Agriculture (USDA).

[9] Nagaraj M. K., C. Subhash. et. al, "Runoff Estimation Using GIS Technique." Proceedings of theInternational Conference on Hydrology and Watershed Management, 2002 Dec 18 to 20, Vol-II, Editors B. Venketeshwara Rao, et. al, pp. 466-473.

[10] Pandey A. and sahu A. K., "Estimation of Runoff Using and Geographic Information System." Proceedings of the International Conference on Hydrology and Watershed Management Dec 18 to 20, Vol-II, Editors B. Venketeshwara Rao, et. al, 2002, pp. 503-509.

\section{Author Profile}

Miss. R.Vinithra received the B.E degree in Civil Engineering from Anna University Tuticorin, Tamilnadu in 2014. She is studying M.Tech Degree in Remote Sensing and GIS from Adhiyamaan College of Engineering, Hosur. Her research area includes remote sensing and GIS.

Dr. L. Yeshodha received the B.E degree in Civil (Transportation) Engineering from Banglore University, Banglore, Karnataka in
1988. The M.E degree in water resources Engineering from Banglore university, Banglore , Karnataka in 1997 and the Ph.D. degree in Civil Engineering from Anna University, Chennai , Tamilnadu. Currently is a Professor of Civil Engineering Department, Adhiyamaan College of Engineering, Hosur, Tamilnadu. Her teaching and research area includes Hydraulics, Water Resources Engineering and Transportations Systems. 